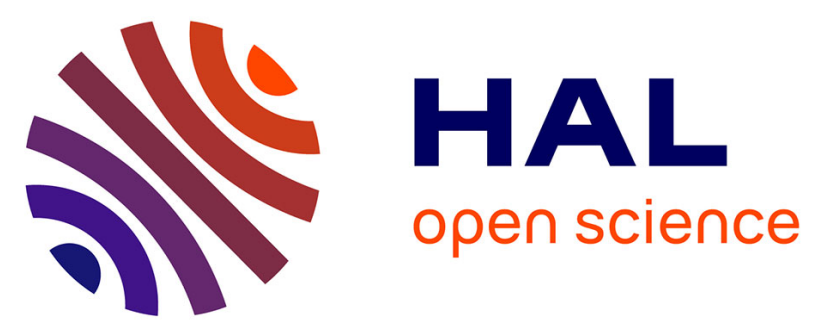

\title{
Fate of Mediterranean Scleractinian Cold-Water Corals as a Result of Global Climate Change. A Synthesis
}

\author{
Cornelia Maier, Markus G Weinbauer, Jean-Pierre Gattuso
}

\section{To cite this version:}

Cornelia Maier, Markus G Weinbauer, Jean-Pierre Gattuso. Fate of Mediterranean Scleractinian Cold-Water Corals as a Result of Global Climate Change. A Synthesis. Covadonga Orejas; Carlos Jiménez. Mediterranean Cold-Water Corals: Past, Present and Future, 9, Springer, pp.517-529, 2019, Coral Reefs of the World, 978-3-319-91607-1. 10.1007/978-3-319-91608-8_44 . hal-02345589

\section{HAL Id: hal-02345589 \\ https://hal.science/hal-02345589}

Submitted on 4 Nov 2019

HAL is a multi-disciplinary open access archive for the deposit and dissemination of scientific research documents, whether they are published or not. The documents may come from teaching and research institutions in France or abroad, or from public or private research centers.
L'archive ouverte pluridisciplinaire HAL, est destinée au dépôt et à la diffusion de documents scientifiques de niveau recherche, publiés ou non, émanant des établissements d'enseignement et de recherche français ou étrangers, des laboratoires publics ou privés. 
archives-ouvertes

\title{
Fate of Mediterranean Scleractinian Cold-Water Corals as a Result of Global Climate Change. A Synthesis
}

\author{
Cornelia Maier, Markus Weinbauer, Jean-Pierre Gattuso
}

\section{To cite this version:}

Cornelia Maier, Markus Weinbauer, Jean-Pierre Gattuso. Fate of Mediterranean Scleractinian ColdWater Corals as a Result of Global Climate Change. A Synthesis. Mediterranean Cold-Water Corals: Past, Present and Future, 2019, 10.1007/978-3-319-91608-8_44 . hal-02345589

\section{HAL Id: hal-02345589 \\ https://hal.archives-ouvertes.fr/hal-02345589}

Submitted on 4 Nov 2019

HAL is a multi-disciplinary open access archive for the deposit and dissemination of scientific research documents, whether they are published or not. The documents may come from teaching and research institutions in France or abroad, or from public or private research centers.
L'archive ouverte pluridisciplinaire HAL, est destinée au dépôt et à la diffusion de documents scientifiques de niveau recherche, publiés ou non, émanant des établissements d'enseignement et de recherche français ou étrangers, des laboratoires publics ou privés. 


\title{
Fate of Mediterranean Scleractinian Cold-Water Corals as a Result of Global Climate Change. A Synthesis
}

\author{
Cornelia Maier, Markus G. Weinbauer, \\ and Jean-Pierre Gattuso
}

\begin{abstract}
This chapter addresses the question as to how Mediterranean cold-water corals might fare in the future under anthropogenically-induced global climate change. The focus on three most prominent scleractinian coldwater corals species, the two branching and habitatforming forms Madrepora oculata, Lophelia pertusa and the solitary cup coral Desmophyllum dianthus. We provide an introduction to climate change principals, highlight the current status of the marine environment with regard to global climate change, and describe how climate change impacts such as ocean acidification are predicted to affect key calcifiers such as scleractinian cold-water corals in the Mediterranean region. A synthesis of the experimental cold-water coral studies conducted to date on climate change impacts: The present state of knowledge reviewed in this chapter takes into account the number of experiments that have been carried out in the Mediterranean as well as for comparative purposes in other parts of the world, to examine the effects of climate change on the corals. We assess the statistical robustness of these experiments and what challenges the presented experiments. A comprehensive multi-study comparison is provided in order to inform on the present state of knowledge, and knowledge gaps, in understanding the effects of global climate change on cold-water corals. Finally we describe what the fate could be for the important scleractinian coral group in the Mediterranean region.
\end{abstract}

\section{Keywords}

Mediterranean cold-water coral $\cdot$ Climate change $\cdot$ Ocean acidification $\cdot$ Temperature $\cdot$ Calcification $\cdot$ Respiration

C. Maier $(\bowtie) \cdot$ M. G. Weinbauer · J.-P. Gattuso Laboratoire d'Oeéanegraphie de Villefranche, Sorbonne Universités, UPMC Univ Paris 06, CNRS INSU, Villefranche-sur-Mer, Franee,

\subsection{Introduction}

\subsubsection{Global Climate Change}

Climate change refers to a change in weather conditions over a longer period of time, taking place from decades to millions of years and usually referring to (regional) rise or fall of mean temperatures, changes in precipitation and parameters such as the frequency of extreme weather events. Throughout Earth's history long-term climate change and climate events have taken place as a consequence of internal or external forcing of the naturally occurring climate system. The most recent, relatively short-term change in the global climate however, has been more dramatic and due to anthropogenically produced greenhouse gases that have acted on the climate system by reducing the heat radiation to space. Anthropogenically induced global warming trend had already been described in the late nineteenth century (Arrhenius 1896). At that time, the contribution of industrially produced $\mathrm{CO}_{2}$ was thought to have minor effects with respect to the overall natural climate dynamics and it was believed that the observed warming would at least be partially beneficial to human prosperity: "...there is good mixed with the evil. ..., we may hope to enjoy ages with more equable and better climates, especially as regards the colder regions of the earth..." (Arrhenius 1908). Since this time research to investigate climate change impacts has intensified and there is now strong evidence, that besides the increase in temperature, our global climate has become less stable with more frequent and intense weather events due to the present day atmospheric levels of $\mathrm{CO}_{2}$ concentration being higher than at any time during the last 2.6 million years (Lewandowsky et al. 2016). Since pre-industrial times, atmospheric $\mathrm{CO}_{2}$ increased from 280 to $400 \mathrm{ppm}$ and a further doubling is projected until the end of the century (IPCC 2013). This rate of change is unprecedented with a anthropogenic $\mathrm{CO}_{2}$ release rate being 14,000 times faster than the natural net release of $\mathrm{CO}_{2}$ (Zeebe et al. 2016).
39 


\subsubsection{The Role of the Oceans}

The oceans play an important role in global climate through gas and heat exchange and it is this thermal capacity of the oceans that moderates the climate and slows down global warming. Heat exchange with the ocean affects the upper ocean layers more strongly than the deep ocean and up to $90 \%$ of the additional heat and about one third of anthropogenic $\mathrm{CO}_{2}$ released since pre-industrial times has been absorbed by the oceans. Since the 1970s ocean temperatures too have increased by $0.11{ }^{\circ} \mathrm{C}$ per decade in the upper $75 \mathrm{~m}$ and by $0.015{ }^{\circ} \mathrm{C}$ at $700 \mathrm{~m}$ water depth (Levitus et al. 2012; Rhein et al. 2013). An apparent 'hiatus' in global warming and sea surface heat uptake during the last 15 years had been identified (IPCC 2013), while the deeper ocean has contributed significantly to an additional and recent heat sequestration. This factor explains the observed slowing down of atmospheric warming during the last decade (Hansen et al. 2011; Meehl et al. 2011; Chen and Tung 2014; Cheng et al. 2015; Yan et al. 2016; Desbruyères et al. 2016; Bova et al. 2016), with recent research substantiating the ongoing ocean warming trend (Kosaka and Xie 2013; Karl et al. 2015; Lewandowsky et al. 2016; Fyfe et al. 2016; Song et al. 2016; Hausfather et al. 2017). Global change not only affects the general heat content and warming of the oceans, but has widespread consequences related to the temperature dependent state of water as solid ice, liquid or vapour. Changes in sea level, salinity and freshwater content show strong regional trends dependent on the ratio of evaporation, precipitation, river discharge and melting of glaciers and ice caps (Church et al. 2011; Pierce et al. 2012; Levermann et al. 2013; Rhein et al. 2013). Since the 1950s the contrast between high- and low-salinity regions has increased by 0.13 (Rhein et al. 2013). These changes in seawater temperature and salinity affect the density and volume of seawater causing changes to the steric sea level (Antonov et al. 2002; Llovel et al. 2014), circulation of water masses and to ocean currents (Purkey and Johnson 2010; England et al. 2014; McGregor et al. 2014).

\subsubsection{Ocean Acidification}

Anthropogenic $\mathrm{CO}_{2}$ released to the atmosphere is partially taken up by the oceans and acts as a major net sink for anthropogenic carbon (Revelle and Suess 1957; Orr et al. 2001; Sabine et al. 2004; Landschützer et al. 2016). Since pre-industrial times about $25-30 \%$ of atmospheric $\mathrm{CO}_{2}$ has been absorbed by the oceans. The rising partial pressure of $\mathrm{CO}_{2}\left(\mathrm{pCO}_{2}\right)$ has major consequences as $\mathrm{CO}_{2}$ reacts to carbonic acid in solution resulting in the reduction of ocean $\mathrm{pH}$ termed ocean acidification (OA). There is an increasing awareness that climate change is altering the physical and biogeochemical status of the surface ocean and with the simultaneous increase of hydrogen and bicarbonate ions and a decrease in carbonate ions the seawater $\mathrm{pH}$ will decline by an average 0.3 units by the end of the century (Caldeira and Wickett 2003; Cicerone et al. 2004; Feely et al. 2004; Sabine et al. 2004; Orr et al. 2005b; Gattuso et al. 2015). This change also affects the calcium carbonate saturation state $(\Omega)$ in seawater which is the discriminant parameter with respect to the precipitation and solution of calcium carbonates. Solubility increases at higher pressure and lower temperature, which means that $\Omega$ decreases with increasing water depths and at higher latitudes. OA has been postulated to be of a major concern for various calcifying organisms as they depend on the surrounding seawater to build their shells or in the case of cold-water corals (CWCs), their skeletons (Orr et al. 2005a, b; Kleypas et al. 2006). Over the last decade research on the effects of OA on marine organisms has intensified and new priorities for future research identified. OA impacts have highlighted the urgent need to study keystone species, ecosystem engineers and those ecosystems considered most vulnerable or most resilient to global climate change (Riebesell and Gattuso 2015). Like their tropical counterparts, scleractinian CWCs grow an aragonitic 3-D matrix like exoskeleton, and as such are susceptible to changes in the seawater carbonate chemistry. The surface ocean is currently supersaturated in aragonite and calcite, the two forms of carbonate that marine calcifiers use to form their shells or skeletons. The ongoing absorption of atmospheric $\mathrm{CO}_{2}$ by the oceans results in a shallowing of the aragonite saturation horizon (ASH), the critical depth between precipitation and dissolution of aragonitic calcium carbonate. Work by Feely et al. (2012) showed that the offset in the ASH in the South Pacific between the 1990s and the 2000s had shifted by $10 \mathrm{~m}$. In the New Zealand region estimates suggest that the ASH may have already shoaled by an order of 50 to $100 \mathrm{~m}$ (Bostock et al. 2013, 2015; Law et al. 2016). This places the deep-sea aragonitic scleractinian CWCs, being confined to the deep waters and to colder regions at great risk with $70 \%$ of the CWC habitats becoming exposed to undersaturated conditions (Guinotte et al. 2006; Mikaloff-Fletcher et al. 2006; Bostock et al. 2015). Scleractinian CWC ecosystems are thought to be one of the most vulnerable groups that will be impacted by global climate change. This factor and additional anthropogenic stressors such as deep-sea trawling, mineral exploration, mining, and marine pollution (Turley et al. 2007; Roberts et al. 2016), add to the vulnerability of CWCs in a high $\mathrm{CO}_{2}$ world.

\subsubsection{Cold-Water Corals}

While the biology of shallow-water tropical corals and their response to global change (warming and OA) has been studied for many decades, research on the biology and physi- 
ology of deep-sea CWCs such as the abundant scleractinian coral group is still in its infancy (but see Reynaud and Ferrier-Pagès, this volume and references therein). Until a decade ago knowledge was based on few studies providing some insights on skeletal extension (Bell and Smith 1999; Mortensen 2001), food capture (Mortensen 2001), potential food sources (Kiriakoulakis et al. 2005; Duineveld et al. 2007), the respiratory response to temperature change or hypoxia (Dodds et al. 2007) and reproductive ecology (Waller and Tyler 2005; Waller et al. 2005). However, the knowledge on the abundance and distribution of CWCs has advanced rapidly since the 1990s due to several factors such as an increase in deep-sea biodiversity surveys (e.g. Zibrowius and Gili 1990; Rogers 1999; Roberts et al. 2009; Buhl-Mortensen et al. 2010; Mastrototaro et al. 2010; Tittensor et al. 2010; Gori et al. 2013; Smith and Williams 2015); access to more sophisticated deep-sea technology facilitating surveys in deeper water over larger areas (e.g. Hovland et al. 2002; Sumida et al. 2004; Taviani et al. 2005; Wheeler et al. 2007; Freiwald et al. 2009; Orejas et al. 2009; De Mol et al. 2011; Gori et al. 2013; Savini et al. 2014; Clippele et al. 2016; see also Angeletti et al., this volume; Lo Iacono et al., this volume), and in several regions, primarily due to fishing activity and fisheries research surveys where the bycatch of deep-sea corals has occurred (e.g. Fosså et al. 2002; Gass and Willison 2005; Hourigan 2009; Tracey et al. 2011; Clark et al. 2015). This growing knowledge of the presence and spatial distribution of CWCs allowed to model and identify the most important parameters supporting or limiting CWC distribution and habitat suitability (Davies et al. 2008; Davies and Guinotte 2011; Tracey et al. 2011; Rowden et al. 2013; Anderson et al. 2016). Among a multitude of environmental and geographic variables taken into consideration depth, temperature, salinity and aragonite saturation state $\left(\Omega_{\mathrm{a}}\right)$ appear to be some of the most important factors controlling the abundance and distribution of CWCs. Additionally, the knowledge on the physiology and growth of $\mathrm{CWCs}$ has rapidly advanced during the last decade (Lartaud et al., this volume; Reynaud and Ferrier-Pagès, this volume) owing to an increased effort in sampling live CWCs and in establishing aquarium facilities that allow to maintain CWCs for an extended time in the laboratory (see Orejas et al., this volume and references therein).

\subsubsection{Climate Change in the Mediterranean Region}

The Mediterranean region has been identified as one among the most important climate change Hot-Spots world-wide as it has become warmer and drier throughout the twenty-first century (Giorgi 2006). The variability in warming during summer is twice the global standard deviation (Hansen and Sato 2016). With this large increase in variability and a decrease in mean precipitation during the dry, warm seasons the Mediterranean constitutes one of the most responsive and affected regions with respect to global change (Giorgi et al. 2001; Giorgi and Lionello 2008; Mariotti et al. 2008; Alessandri et al. 2014).

The Mediterranean Sea is nearly land-locked, connected to the Atlantic by the shallow $(300 \mathrm{~m})$ Strait of Gibraltar. Evaporation greatly exceeds precipitation which drives the thermohaline circulation with deep and intermediate dense water convection in several basins and a unique open upper thermohaline cell that acts in a similar way as the global conveyer belt while it is characterised by a much shorter residence time of ca. 100 years (Malanotte-Rizzoli et al. 2014; Hayes et al., this volume). Therefore, the waters respond faster and are more sensitive to environmental change and thus can be regarded as a miniature model ocean (Bethoux et al. 1990, 1998; Bethoux and Gentili 1996; Turley 1999). Over the last decades, the trends of long-term warming and saltening have been evidenced throughout the Mediterranean Sea (Bethoux et al. 1990; Rixen et al. 2005; Nykjaer 2009; Vargas-Yáñez et al. 2009). Based on model simulations, an increase in sea surface temperature and sea surface salinity (SST and SSS) by 2 to $3{ }^{\circ} \mathrm{C}$ and 0.48 to 0.89 are predicted for 2070-2099. This is in comparison to $~ 30$ years of SST and SSS data measured between 1961-1990 (Adloff et al. 2015). The trend has also increased at depth, where a temperature and salinity increase of $0.93-1.35{ }^{\circ} \mathrm{C}$ and 0.28 to 0.52 respectively has occurred throughout the water column. At the depths that scleractinian CWCs occur in the Mediterranean (below $200 \mathrm{~m}$ ), the predicted temperature rise may increase by up to $2{ }^{\circ} \mathrm{C}$ and the salinity by $\sim 0.5$. Accordingly, Mediterranean CWCs might be exposed to a temperature between 15.5 to $16{ }^{\circ} \mathrm{C}$ and a salinity of 39.5 to 40 by the end of the century.

The Mediterranean Sea is characterised by a high total

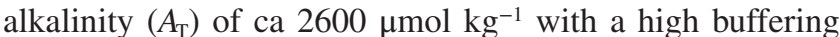
capacity absorbing more $\mathrm{CO}_{2}$ than the open ocean (CIESM 2008). It is a small to medium sink for $\mathrm{CO}_{2}$ absorbing ca. $0.24 \mathrm{Gt} \mathrm{C}$ year $^{-1}$ (D'Ortenzio et al. 2008) while the reduction of ocean $\mathrm{pH}$ is relatively fast with -0.14 to $-0.05 \mathrm{pH}$ units year $^{-1}$ (Touratier and Goyet 2009, 2011). Despite this, the $\Omega$ remains higher in the deep Mediterranean waters compared to the deep waters of the North Atlantic (Millero et al. 1979), and even at the deepest water depths the seawater is not likely to become undersaturated with respect to $\Omega_{\mathrm{a}}$ (Hassoun et al. 2015; Goyet et al. 2016). Present day $\Omega_{\mathrm{a}}$ reported in the vicinity of Mediterranean CWCs are relatively high ranging between 2.3 and 3.0 (Rodolfo-Metalpa et al. 2015; Maier et al. 2016) but will drastically decrease to ca. 1.5 by the end of the century (Maier et al. 2016). 


\subsubsection{Effect of Climate Change Parameters on Cold-Water Corals}

To date 24 experimental studies have been published on the physiological response of scleractinian CWCs to climate change and these studies, from both the Mediterranean and elsewhere, are summarised in Table 44.1. Nineteen of these studies addressed the effect of OA, eight the effect of temperature, four took into account the combined effect of OA and temperature. No studies are available on the effect on CWCs to changes in salinity. Interestingly, $40 \%$ of the studies were conducted using CWCs from the Mediterranean Sea region. The studies comprise five scleractinian coral species (Madrepora oculata, Lophelia pertusa, Desmophyllum dianthus, Dendrophyllia cornigera and Caryophyllia smithii), while most of the non-Mediterranean CWC studies were confined to the species L. pertusa (Table 44.1). The studies were distinct with respect to the time allowed for acclimation, replication and the use of single (Fig. 44.1), consecutive (Fig. 44.2) or repeated (Fig. 44.3) measure designs. Most studies were carried out in the laboratory, some short-term experiments were conducted at sea using freshly collected specimens and seawater from the actual sampling site (Maier et al. 2009, 2012; Hennige et al. 2014) and one other Mediterranean study included in situ experiments where coral fragments were transplanted to the close vicinity of a natural $\mathrm{CO}_{2}$ vent site (Rodolfo-Metalpa et al. 2015). To provide an indication on the statistical robustness of the experimental studies a point system was introduced ("SR"; Table 44.1) taking into account criteria such as the number of replication, number of repeated measurements and the type of controls. Theoretically, a minimum point score of 3 and a maximum of 11 was possible, and an average SR of 5.7 points $( \pm 1.4$ S.D) was typical for the studies (Table 44.1). This point system is not exclusive with respect to other criteria that may be important to evaluate the robustness of a study (e.g. handling stress, sampling and analytical procedures, adequacy of maintenance conditions), however, these criteria are difficult to judge in a scoring system.

\subsection{Ocean Acidification Studies}

The $\mathrm{pCO}_{2}$ used in most of the $\mathrm{OA}$ experimental studies ranged between ambient (ca. $400 \mu \mathrm{atm}$ ) and 800-1000 $\mu \mathrm{atm}$, corresponding to current and future conditions in 2100 using a business-as-usual $\mathrm{CO}_{2}$ emission scenario. The exception was for two short-term experiments where $\mathrm{pCO}_{2}$ levels in which $\mathrm{pCO}_{2}$ values outside this range were used: $280 \mu \mathrm{atm}$ to represent pre-industrial times (Maier et al. 2012) and $1725 \mu \mathrm{atm}$ (Maier et al. 2016). The first studies of the effect of OA were performed on Lophelia pertusa. They revealed a negative response of calcification to increasing $\mathrm{pCO}_{2}$ during short- term exposure (Maier et al. 2009; Form and Riebesell 2012) while no effect was detected when exposed for several months to elevated $\mathrm{pCO}_{2}$ (Form and Riebesell 2012). These two studies show that $L$. pertusa is able to maintain positive calcification rates despite being exposed to undersaturated $\Omega_{\mathrm{a}}$ (Maier et al. 2009; Form and Riebesell 2012). Subsequent studies have demonstrated that calcification remains constant for $\mathrm{pCO}_{2}$ levels corresponding to those between present-day $(\sim 400 \mu \mathrm{atm})$ and those projected until the end of the century ( 800-1000 $\mu \mathrm{atm})$ (Figs. 44.1, 44.2, and 44.3). This was found for both short- and long-term exposure and for most CWC species studied, suggesting that no long-term acclimation occurs (Maier et al. 2012, 2013b, 2016; Carreiro-Silva et al. 2014; Hennige et al. 2014; Movilla et al. 2014a, b; Rodolfo-Metalpa et al. 2015). However, some recent literature states that CWCs may exhibit a long-term acclimation response in calcification to OA (Hennige et al. 2015; Roberts et al. 2016). Evidently, calcification is negatively affected in short-term experiments when $\Omega_{\mathrm{a}}$ is below a certain threshold level (Figs. 44.1a, c and 44.2b, c; Maier et al. 2009; Lunden et al. 2014; Georgian et al. 2016b, Maier et al. 2016) but the same is true in long-term experiments (Fig. 44.3d, Hennige et al. 2015). Furthermore, using a repeated measures experimental design, Movilla et al. (2014b) showed a decline in calcification for the Mediterranean coral Desmophyllum dianthus after 314 days of exposure to elevated $\mathrm{pCO}_{2}(800 \mu \mathrm{atm})$, while no effect at shorter exposure times was observed (Fig. 44.3c; Movilla et al. 2014b). This response might be species-specific, as none of the other three species (L. pertusa, Madrepora oculata and Dendrophyllia cornigera) studied in parallel revealed any significant effect between control and elevated $\mathrm{pCO}_{2}$ treatments, neither during short- nor longterm exposure (Movilla et al. 2014a,b). It would have been interesting to see, if calcification of $D$. dianthus remains at the lower level it revealed after 314 days, restores calcification to normal rates or in the worst case scenario, further reduces calcification with increasing exposure time. A result such as this could be indicative of an eventual break down in calcification as a consequence of extended and continuous exposure to elevated $\mathrm{pCO}_{2}$. For $D$. dianthus it has been shown that genes involved in stress response, metabolism or calcification were upregulated under elevated $\mathrm{pCO}_{2}$ levels after a 8-month exposure while the rates of calcification and respiration remained stable (Carreiro-Silva et al. 2014). No time-series on gene expression experiments exist for these species to date, and so it is not known whether an up- or down regulation of genes is dependent on the duration of exposure. While calcification rates are relatively constant over a large range of $\mathrm{pCO}_{2}$ and only decrease after a certain threshold has been reached, faster skeletal linear extension under high $\mathrm{pCO}_{2}$ has been reported for North Atlantic studies on $L$. pertusa (Hennige et al. 2015). This coincides with thinner and longer corallites and an altered mineral organisation that may impact 


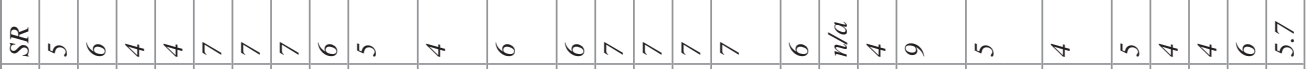

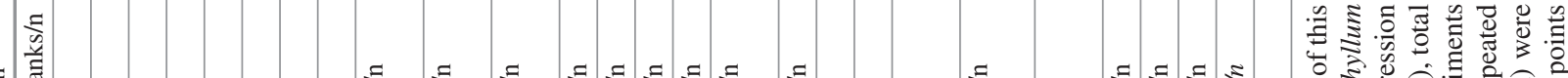

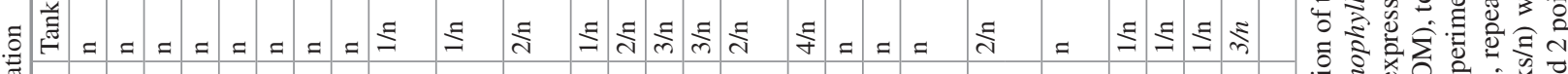

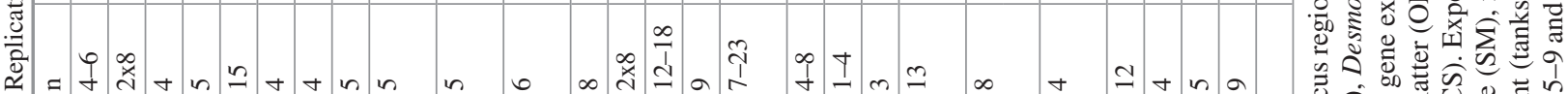

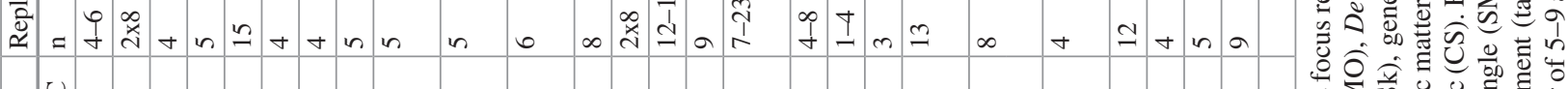

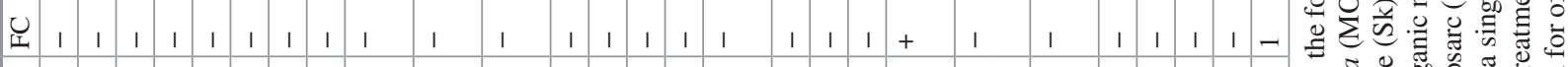

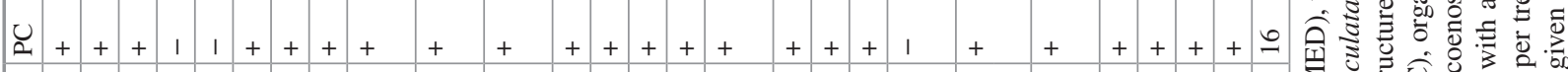

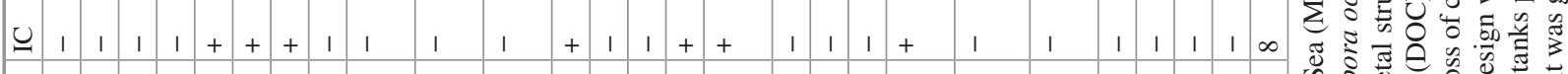

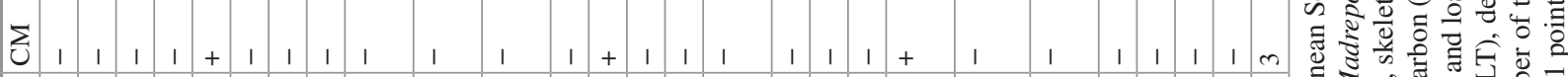

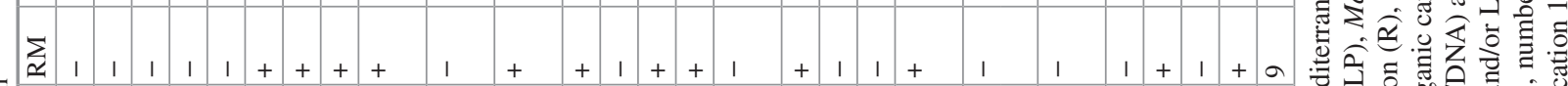
.50

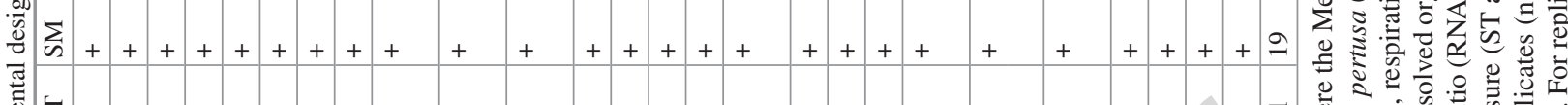
氙 $1111+1++1+++1+1+1++++1+1+1+1+1+=0$

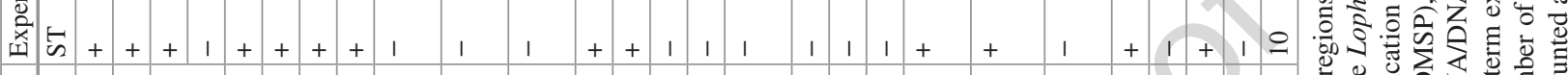

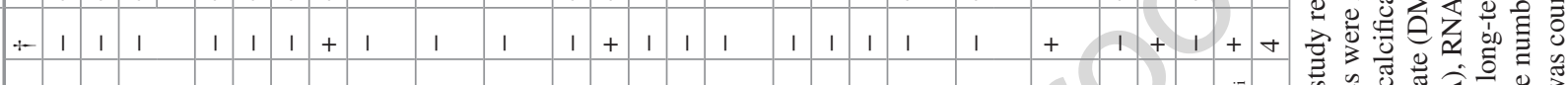

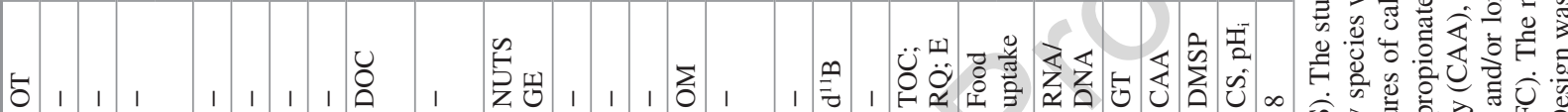

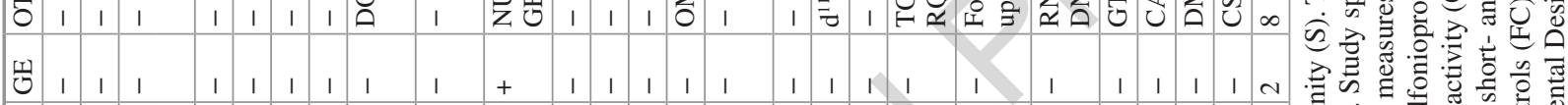

$\simeq+1+1+1+1+$

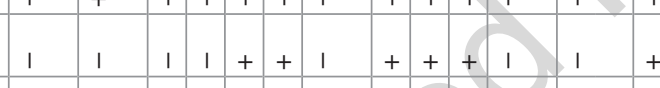

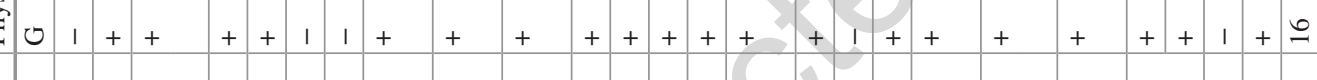

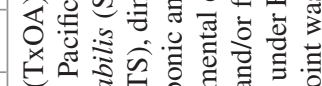
乞 Ч

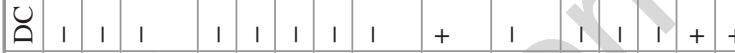

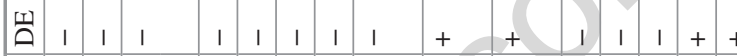
$\stackrel{3}{\frac{3}{2}}$ के

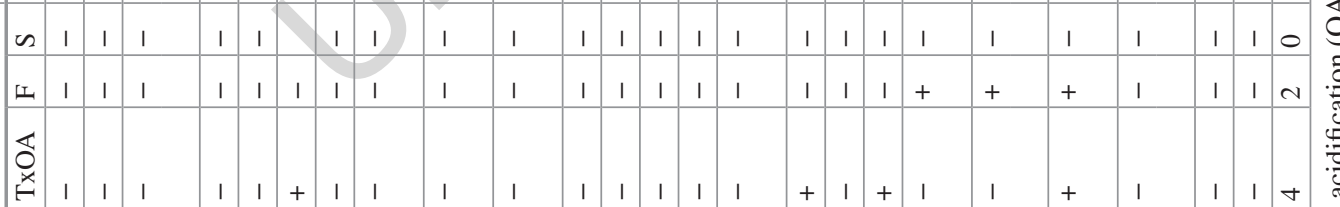

के

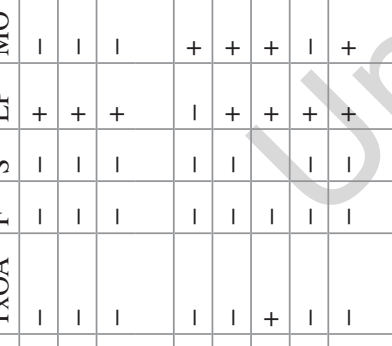

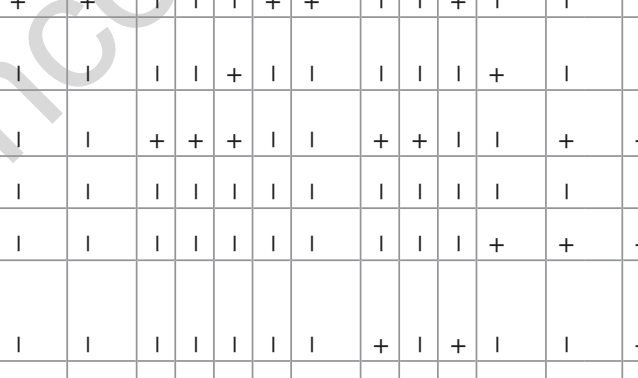

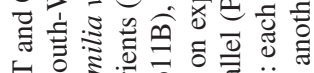

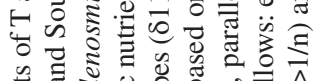
뉸 홍.

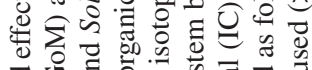

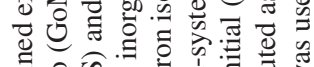

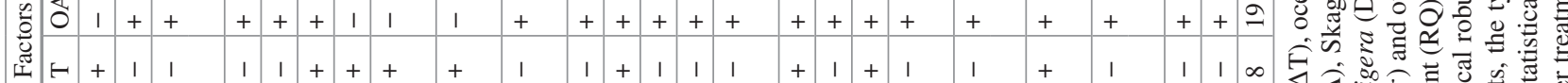
-

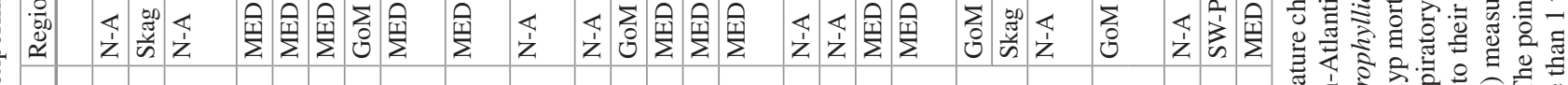

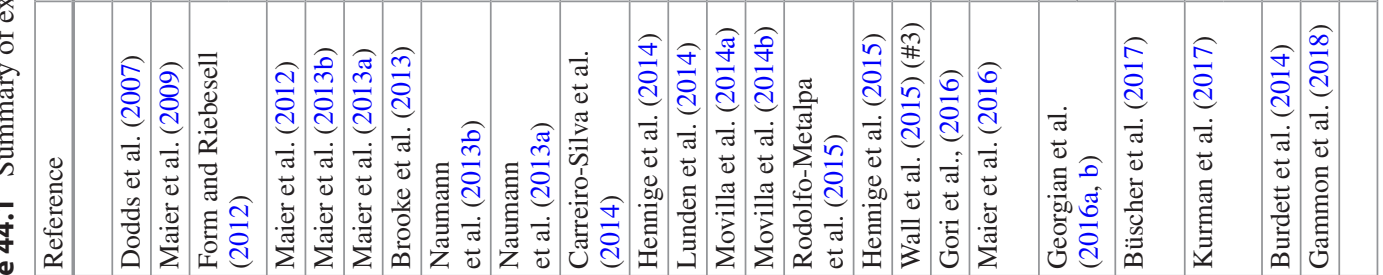

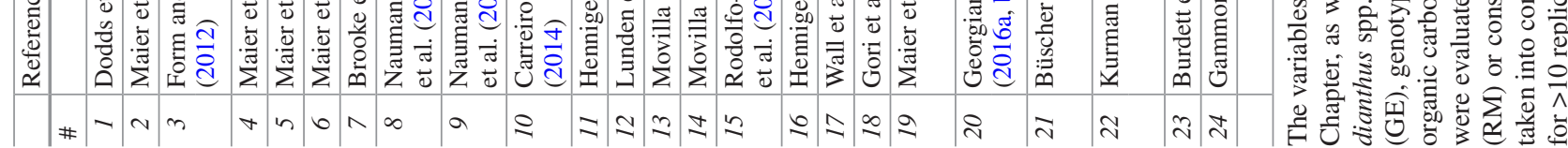

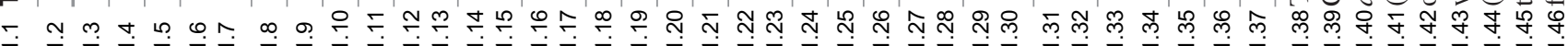

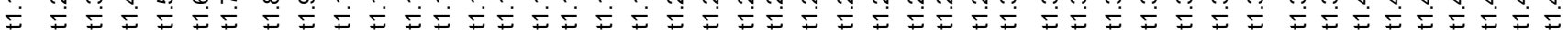


the stability and breaking strength of the skeleton and the stability of the CWC framework. Despite this, changes in the micro-density and porosity were not reported under similar conditions, neither for North Atlantic L. pertusa (Wall et al. 2015) nor Mediterranean CWC species (Movilla et al. 2014a). In a study on a related species Solenosmilia variabilis colonies were grown under ambient $\mathrm{pH}\left(7.88, \Omega_{\mathrm{a}} 0.93\right)$ and lower $\mathrm{pH}$ (7.65, $\Omega_{\mathrm{a}}$ 0.78) for two years (Gammon et al. 2018). Respiration and growth rate were not altered under low $\mathrm{pH}$, although there was a decrease in skeletal colouration attributed to a loss of coenochyme, the tissue connecting neigh- bouring polyps and covering the outer skeleton, indicating the potential reallocation of energy to other physiological processes such as growth and respiration. While there has been two studies where respiration decreased or increased after two weeks during short-term exposure to higher $\mathrm{pCO}_{2}$ (Figs. 44.1c and 44.3a; Hennige et al. 2014; Georgian et al. 2016b) no effect on respiration at increased $\mathrm{pCO}_{2}$ levels has been detected in other studies (Figs. 44.1e-g, 44.2c, and 44.3b, c; Maier et al. 2013a, 2016; Carreiro-Silva et al. 2014; Movilla et al. 2014a, b; Rodolfo-Metalpa et al. 2015; Hennige et al. 2015; Gori et al. 2016; Gammon et al. 2018).
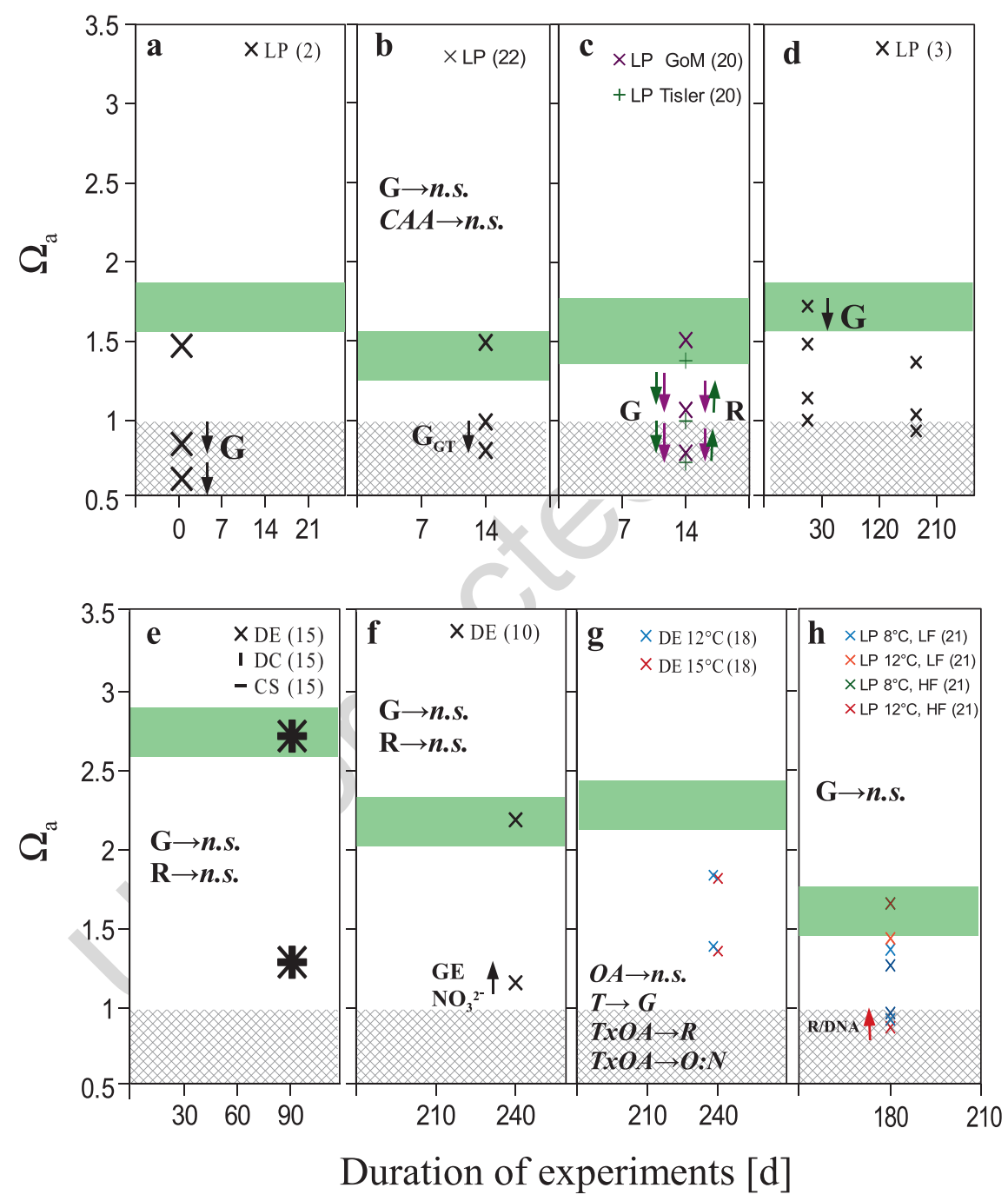

Fig. 44.1 Plot of studies using single-point experimental designs for measurements according to aragonite saturation state $\left(\Omega_{\mathrm{a}}\right)$ in seawater (y-axis) and acclimation time in days (duration of experiments [d], $\mathrm{x}$ axes). The response of physiological functions are shown according to studies (a-h) and include calcification $(\mathrm{G})$, calcification of different genotypes $\left(\mathrm{G}_{\mathrm{GT}}\right)$, respiration $(\mathrm{R})$, gene expression $(\mathrm{GE})$, carbonic anhydrase activity (CAA) and nitrate excretion $\left(\mathrm{NO}_{3}{ }^{2-}\right)$ for the species Lophelia pertusa (LP), Madrepora oculata (MO), Desmophyllum dianthus (DE), Dendrophyllia cornigera (DC), and Caryophyllia smithii (CS). Numbers in brackets refer to the publications referenced in
Table 44.1. For studies addressing combined effects of OA and temperature $(\mathbf{g})$ or OA, temperature and feeding $(\mathbf{h})$ coloured symbols were used. The temperature and high or low food supply (HF and LF) are indicated in the symbol legend. According to the region the ambient $\Omega_{\mathrm{a}}$ varied and is indicated by the green area. The grey area indicates $\Omega_{\mathrm{a}}<1$. Numbers in brackets refer to the publications referenced in Table 44.1. Size of symbols is indicative of number of replicates (n), vertical arrows depict where a significant positive $(\uparrow)$ or negative $(\downarrow)$ response was revealed, while n.s. indicates that there was no significant effect between treatment levels for the respective variable (ㄷ Cornelia Maier) 


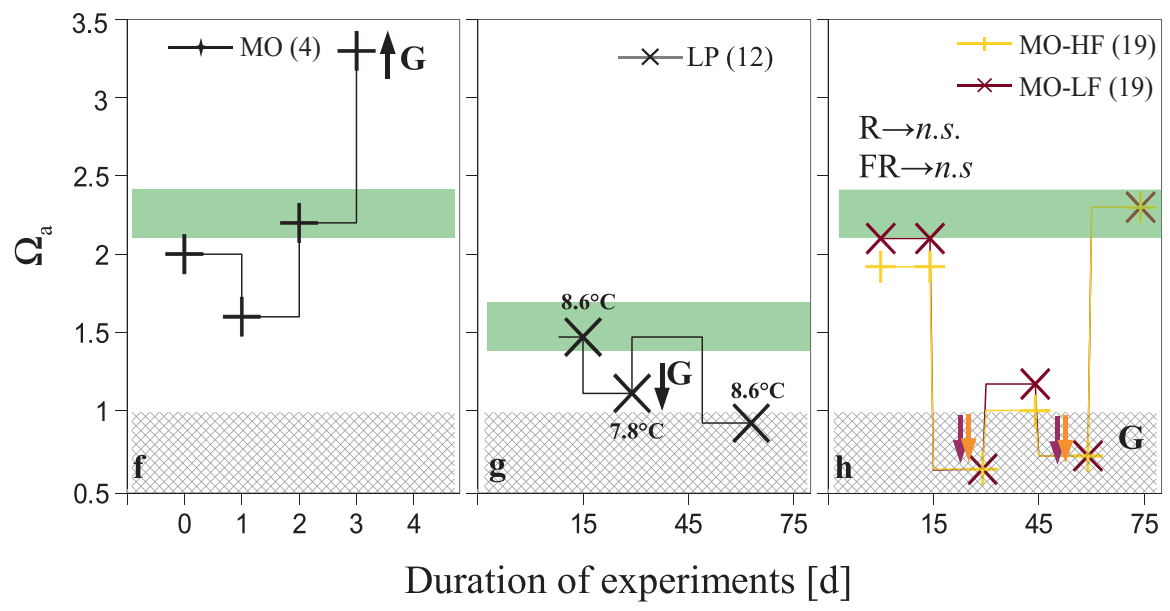

Fig. 44.2 Plot of studies using consecutive experimental designs for measurements according to aragonite saturation state $\left(\Omega_{\mathrm{a}}\right)$ in seawater (y-axis) and acclimation time in days (duration of experiments [d]; $\mathrm{x}$ axes). The symbol lines record changes of $\Omega_{\mathrm{a}}$ during experiments with symbols depicting when calcification $(\mathrm{G})$ or respiration $(\mathrm{R})$ of Lophelia pertusa (LP) or Madrepora oculata (MO) were assessed during the consecutive changes in $\Omega_{\mathrm{a}}$. Numbers in brackets refer to the publications referenced in Table 44.1. Coloured symbols (in $\mathbf{h}$ ) were used to depict the high (HF) and low (LF) food regime. According to the region the ambient $\Omega_{\mathrm{a}}$ varied and is indicated by the green area. The grey area indicates $\Omega_{\mathrm{a}}<1$. Numbers in brackets refer to the publications referenced in Table 44.1. Size of symbols is indicative of number of replicates (n), vertical arrows depict where a significant positive $(\uparrow)$ or negative $(\downarrow)$ response was revealed, while n.s. indicates that there was no significant effect between treatment levels or time steps for the respective variable (@) Cornelia Maier)

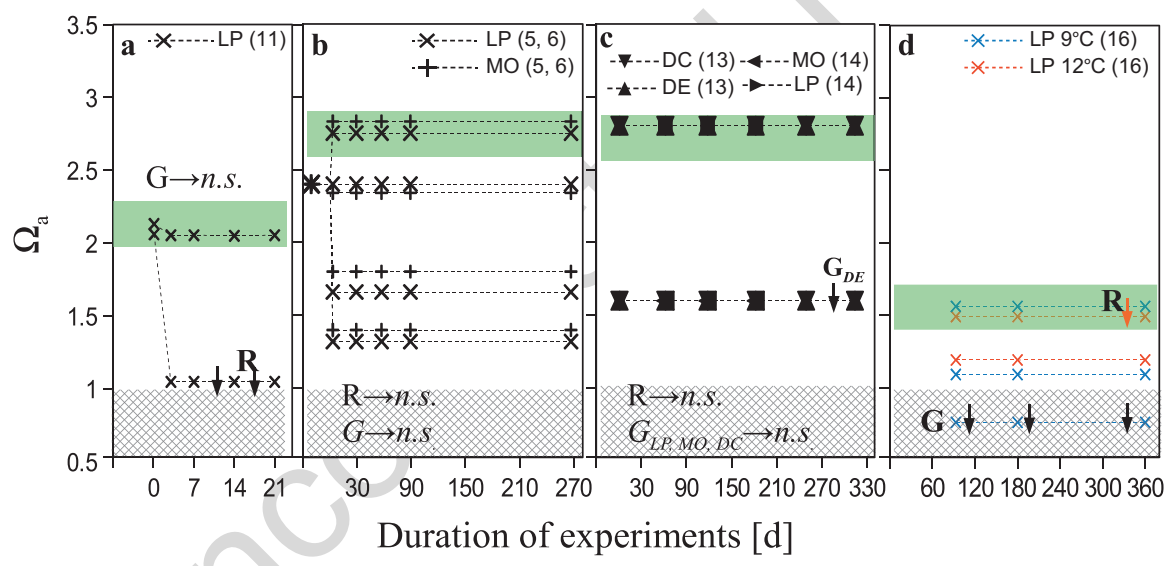

Fig. 44.3 Plot of studies using repeated measurement designs showing measurements points according to aragonite saturation state $\left(\Omega_{\mathrm{a}}\right)$ in seawater (y-axis) and acclimation time in days (duration of experiments [d]; x-axis). The symbol lines record $\Omega_{\mathrm{a}}$ for replicated measurements with symbols depicting when calcification $(\mathrm{G})$ or respiration (R) of L. pertusa (LP), M. oculata (MO), D. dianthus (DE) or D. cornigera (DC) were assessed during the consecutive changes in $\Omega_{\mathrm{a}}$. Numbers in brackets refer to the publications referenced in Table 44.1. According to the region the ambient $\Omega_{\mathrm{a}}$ varied
The apparent high resilience of CWCs to OA in both the experimental studies, described here for the Mediterranean and elsewhere, and also observed in situ (Thresher et al. 2011; Fillinger and Richter 2013; Jantzen et al. 2013; Bostock et al. 2015; Georgian et al. 2016a; Gammon et al. 2018) has been attributed to $\mathrm{pH}$ upregulation of the calicoblastic pH (McCulloch et al. 2012; Wall et al. 2015). The upregulation of calicoblastic $\mathrm{pH}$ has been thought to require and is indicated by the green area. The grey area indicates $\Omega_{\mathrm{a}}<1$. Numbers in brackets refer to the publications referenced in Table 44.1. Coloured symbols were used for the combined effect of $\mathrm{OA}$ and temperature (in d) with the temperature indicated in the symbol legend. Size of symbols is indicative of number of replicates $(\mathrm{n})$, vertical arrows depict where a significant positive $(\uparrow)$ or negative $(\downarrow)$ response was revealed, while n.s. indicates that there was no significant effect between treatment levels or time steps for the respective variable (@ Cornelia Maier)

a high amount of energy and may consequently require high food availability in areas with low $\Omega_{\mathrm{a}}$ to maintain calcification constant (McCulloch et al. 2012; Fillinger and Richter 2013; Jantzen et al. 2013). However, a study establishing an energy budget for major physiological functions of Mediterranean M. oculata revealed that the energy required for calcification in general and for the upregulation of calicoblastic $\mathrm{pH}$ (or $\Omega_{\mathrm{a}}$ ) in particular only constitutes a minor frac- 
tion of about 1 to $3 \%$ of overall metabolic requirements (Maier et al. 2016). Despite a four-fold food uptake in the high feeding group and the respiratory quotient indicating starvation in the low-food group, no mitigating effect on calcification or respiration at increased $\mathrm{pCO}_{2}$ levels due to feeding was reported (Maier et al. 2016). Similarly, in a study on North-Atlantic $L$. pertusa no mitigating effect of feeding has been shown despite a tenfold food availability in the highfood group (Büscher et al. 2017).

However, the need to double the energy allocated to calcification at elevated $\mathrm{pCO}_{2}$ (Maier et al. 2016) might nevertheless constitute a burden over an extended time and permanent exposure to unfavorable conditions. Specifically in an environment where food is permanently scarce, a shift in energy allocation might occur in favor of other physiological functions that may explain the observed decline in calcification of D. dianthus (Movilla et al. 2014b). The decrease in skeletal colouration attributed to a loss of coenochyme seen by Tracey et al. may have also reflected a food scarcity response.

\subsubsection{Temperature}

Of the eight studies assessing the response of CWCs to changes in temperature, two measured the survival of L. pertusa from the Gulf of Mexico at a temperature range from 8 (ambient) to 15,20 and $25^{\circ} \mathrm{C}$ and an exposure time of 1 and 8 days (Brooke et al. 2013) or by changing temperature in consecutive steps from $8,10,12,14$ to $16^{\circ}$, with an adjustment period of 1 day per $2{ }^{\circ} \mathrm{C}$ increment (Lunden et al. 2014). Both studies showed significant mortalities at temperatures $\geq 15^{\circ} \mathrm{C}$ and conclude that the upper temperature limit for the survival of $L$. pertusa would be $15^{\circ} \mathrm{C}$. The projected rise in temperature in the Mediterranean Sea could be as detrimental to the Mediterranean CWCs. However, the experimental design used by Brooke et al. (2013) did not allow for longer term acclimation and was in fact designed to reflect specific conditions prevailing in the Gulf of Mexico, where CWCs can experience occasional flushing by warmwater currents and a rapid and dramatic increase in seawater temperature (Brooke et al. 2013). In the Mediterranean Sea, CWCs are not subject to such an abrupt temperature increase, but they are subject to the high temperatures at the extreme reported for all CWCs. It is for this reason that it has been assumed that the Mediterranean CWCs are already at their upper tolerance limit (ca. $13{ }^{\circ} \mathrm{C}$ ) and any further increase in temperature might therefore be detrimental. Despite this, there is some evidence that Mediterranean CWCs are well adapted to a relatively constant high temperature. In two experiments without prior acclimation phase, a temperature dependent increase or decrease of respiration has been reported for L. pertusa from the North Atlantic (Dodds et al. 2007) and Mediterranean Sea (Maier et al. 2013a, Supplement
SI_1). At ambient temperature, respiration rates of Mediterranean $L$. pertusa were comparable to those from the North Atlantic region despite the $4{ }^{\circ} \mathrm{C}$ temperature difference. The temperature-dependent coefficient of respiration $\left(\mathrm{Q}_{10}\right)$ was lower for Mediterranean L. pertusa than for NorthAtlantic specimen further indicating that Mediterranean $L$. pertusa as being well adapted to the higher temperature and potentially less sensitive to a further increase in temperature than specimen from colder regions. This is further substantiated by the finding by Naumann et al. (2013a, b) and Hennige et al. (2015) who found that no significant changes in respiration were observed when Mediterranean or North Atlantic L. pertusa were acclimated for 3-6 months to lower or higher than ambient temperatures (Naumann et al. 2013a, b; Hennige et al. 2015). However, in the study by Hennige et al. (2015) respiration rates decreased significantly after a total of 9 months exposure to $12{ }^{\circ} \mathrm{C}$. This response is difficult to explain, and with the good replication $(\mathrm{n}=8,4$ tanks $/ \mathrm{n})$ it is not likely caused by experimental constraints such as tank effects. The authors therefore consider "... that normal' energetic strategies are no longer applying, possibly due to other processes using energetic reserves. This could be the result of processes that maybe occurring of which we have poor understanding and/or cannot easily measure" (Hennige et al. 2015). In contrast to $L$. pertusa, respiration of Mediterranean M. oculata significantly decreased when temperature was lowered from 12 to 9 and then down to $6{ }^{\circ} \mathrm{C}$ after a 3-month acclimation (Naumann et al. 2013b). This result led the authors to speculate that $M$. oculata acclimates at a much slower rate to changes in temperature than $L$. pertusa. The results also provide the variable thermal tolerance range for the two species. M. oculata is the dominant species in the Mediterranean, while L. pertusa prevails in colder regions like the North Atlantic. This preferred distribution for both species could indicate that $L$. pertusa acclimates faster to colder temperature than M. oculata and conversely, that $M$. oculata acclimates more easily to increasing temperatures. To date, no longer term study with respect to increasing temperature tolerance exists for these two species and no final conclusion can be made as to: how these two species may acclimate to the ongoing warming in the Mediterranean Sea. For calcification responses, the Mediterranean D. cornigera revealed a significant increase in calcification at $17.5{ }^{\circ} \mathrm{C}$ while a slight but non-significant reduction to $83 \%$ was reported for $D$. dianthus at $17.5{ }^{\circ} \mathrm{C}$ (Naumann et al. 2013a). When the temperature was lowered from 12 to 9 to $6{ }^{\circ} \mathrm{C}$, calcification of M. oculata and L. pertusa was faster at the higher temperature levels in both species. While calcification of $M$. oculata significantly decreased at each temperature step, calcification of $L$. pertusa was only significantly lower at $6^{\circ}$, and between 12 to $9{ }^{\circ} \mathrm{C}$ only a slight, non-significant decrease was observed (Naumann et al. 2013b). For North Atlantic L. pertusa the response 
differed, showing a slight decrease in calcification to 82 and $70 \%$ after exposure of 3 and 6 months to higher $\left(12^{\circ} \mathrm{C}\right)$ than ambient $\left(9^{\circ} \mathrm{C}\right)$ temperature, while calcification increased to 1.5 times that at ambient temperature after a total of 9 months (Hennige et al. 2015, Fig. 44.3d). The study on Mediterranean D. dianthus by Gori et al. (2016) reported a significant and negative effect on calcification when temperature was increased from 12 to $15{ }^{\circ} \mathrm{C}$. When subjected to both elevated temperature and $\mathrm{pCO}_{2}$, however, there was no significant calcification effect and the opposite result was found for respiration (Gori et al. 2016). The experimental approach of the Gori et al. (2016) study was interesting and timely as the authors tackled the question of single and combined effects of temperature and $\mathrm{OA}$ impacts with the temperature and $\mathrm{pCO}_{2}$ levels representative of projected changes in the Mediterranean Sea. However, the statistical robustness of the experiment was limited, due to a low number of sample replicates $(n=3)$ (Table 44.1). The results are useful as they provide a first indication as to how Mediterranean $D$. dianthus would respond to long-term increasing temperature; however the results require some consolidation.

This can also be said for the general perception that CWCs in the Mediterranean Sea are at their upper tolerance limit with respect to temperature. There is evidence that at least some of the species may be able to cope with increasing temperatures but overall there needs to be some caution before drawing this conclusion. It is important to consider in the first instance experimental design (duration of experiments, sample sizes, replication, and controls), as well as other environmental stressors, before any assumptions can be made when assessing the physiological response of these corals to changes in temperature.

\subsubsection{Salinity}

As a consequence of global change, the salinity in the Mediterranean Sea will increase by $\sim 0.5$ at the depths of CWC occurrence (see Skliris, this volume and references herein). Despite this fact, and that the current salinity levels are the highest reported for CWC occurrence in any one area, no studies are available on the physiological response of CWCs to increasing salinity. In addition to this and of significance is that climate change models need to take into account the ever growing need of freshwater in this region as consequence of a growing population and a higher consumption per capita. The construction of desalination plants along Mediterranean shorelines has intensified during the last decades several times over to generate fresh water. While $50 \%$ of the seawater is converted to drinking water the other $50 \%$ is discharged back into the sea as concentrated brine. For the Mediterranean Sea, it has been estimated that the salinity due to brine discharge will increase by an additional
$0.81 \mathrm{~g} / \mathrm{L}$ until 2050 (Bashitialshaaer et al. 2011). This situation means that together with the salinity increase due to climate change, the salinity may rise to above levels of around 40 , which is comparable to the salinity of the Red Sea. The Red Sea is renowned for its thriving tropical coral reefs and one may therefore speculate that this increase in salinity may not impact Mediterranean CWCs. However, a high sensitivity to small changes in salinity has been reported for the tropical coral S. pistillata found in the region and that appeared to acclimate more easily to a decline than to an increase in salinity (Ferrier-Pagès et al. 1999). As with temperature, salinity is the highest reported in the Mediterranean region experienced by $\mathrm{CWC}$ habitats to date. It will therefore be important to study the response of Mediterranean CWCs to the added stress of an increase in salinity, particularly in light of the additional climate related impacts due to brine discharge that will potentially accelerate the increase in salinity during the coming decades.

\subsection{Conclusions}

It has been shown in a number of studies that CWCs exhibit a high resilience to OA and may be able to maintain calcification and respiration rates constant over a large gradient in $\mathrm{pCO}_{2}$. There is robust evidence that with the projected $\Omega_{\mathrm{a}}$ remaining above a level of 1 , Mediterranean $\mathrm{CWC}$ growth might not be as impacted by OA despite the projected and relatively fast decline in seawater $\mathrm{pH}$. The studies summarised in this chapter indicate that there is potentially some hope for some of Mediterranean CWC study species with some groups able to acclimate to an increase in temperature and withstand ocean acidification. However, upper tolerance limits (thresholds) for single climate change parameters still need to be consolidated for each species. This is particularly so for Mediterranean CWCs that are being exposed to additional stressors such as an increase in salinity or pollution. It will be pivotal to address the effect of the concomitant increase in temperature, $\mathrm{pCO}_{2}$, and salinity to ultimately conclude on the potential fate of Mediterranean CWC species in the near future as both calcification and respiration reveal a strong acclimation response to temperature.

It is acknowledged that further work is required to tease out the impacts of multiple stressors on the CWCs. Some species may appear to be able to tolerate temperature and OA impacts but at what expense of other biological processes. The various aspects of human induced salinity changes need to be investigated, particularly as the availability of water to growing populations and agriculture will grow in demand. Also important will be to quantify the saturation state of aragonite $\left(\Omega_{\mathrm{a}}\right)$ within the calcifying fluid of corals as this is critical for understanding their biomineralisation process and sensitivity to environmental changes including ocean acidification. 
Acknowledgements The authors would like to thank the editor and the reviewers Marina Carreiro-Silva and Di Tracey for constructive criticism, with special thanks to Di for the additional time put into editing the English and providing additional references broadening the geographic range with respect to CWCs and climate studies.

\section{References}

Adloff F, Somot S, Sevault F, et al (2015) Mediterranean Sea response to climate change in an ensemble of tyenty first century scenarios. Clim Dyn 45:2775-2802. https://doi.org/10.1007/ s00382-00015-02507-00383

Alessandri A, Felice MD, Zeng N, et al (2014) Robust assessment of the expansion and retreat of Mediterranean climate in the 21st century. Sci Rep 4:7211. https://doi.org/10.1038/srep07211

Anderson OF, Guinotte JG, Rowden AA, et al (2016) Habitat suitability models for predicting the occurrence of vulnerable marine ecosystems in the seas around New Zealand. Deep-Sea Res Part 1 Oceanogr Res Pap 115:265-292

Antonov JI, Levitus S, Boyer TP (2002) Steric Sea level variations during 1957-1994: importance of salinity. J Geophys Res 107:8013. https://doi.org/10.1029/2001JC000964

Arrhenius S (1896) On the influence of carbonic acid in the air upon the temperature of the ground. Philos Mag Ser 41:237-276

Arrhenius S (1908) Worlds in the making. The evolution of the Universe, vol. Harper \& Brothers Publishers, New York, London, $264 \mathrm{p}$

Bashitialshaaer RAI, Persson KM, Aljaradin M (2011) Estimated future salinity in the Arabian Gulf, the Mediterranean Sea and the Red Sea. Consequences of brine discharge from desalination. Int J Acad Res 3:133-140

Bell N, Smith J (1999) Coral growing on North Sea oil rigs. Nature 402:601

Bethoux JP, Gentili B (1996) The Mediterranean Sea, coastal and deepsea signatures of climatic and environmental changes. J Mar Syst 7:383-394

Bethoux JP, Gentili B, Raunet J, et al (1990) Warming trend in the western Mediterranean deep water. Nature 347:660-662

Béthoux J-P, Gentili B, Tailliez D (1998) Warming and freshwater budget changes in the Mediterranean since the 1940s: their possible relation to the greenhouse effect. Geophys Res Lett 25:1023

Bostock HC, Mikaloff-Fletcher SE, Williams MJM (2013) Estimating carbonate parameters from hydrographic data for the intermediate and deep waters of the Southern Hemisphere oceans. Biogeosciences 10:6199-6213

Bostock HC, Tracey DM, Currie KI, et al (2015) The carbonate mineralogy and distribution of habitat-forming deep-sea corals in the Southwest Pacific region. Deep-Sea Res Part 1 Oceanogr Res Pap 100:88-104

Bova SC, Herbert TD, Fox-Kemper B (2016) Rapid variations in deep ocean temperature detected in the Holocene. Geophys Res Lett 43:12190-12198. https://doi.org/10.1002/2016GL071450

Brooke S, Ross SW, Bane JM, et al (2013) Temperature tolerance of the deep-sea coral Lophelia pertusa from the southeastern United States. Deep-Sea Res Part 2 Top Stud Oceanogr 92:240-248

Buhl-Mortensen L, Vanreusel A, Gooday AJ, et al (2010) Biological structures as a source of habitat heterogeneity and biodiversity on the open ocean margins. Mar Ecol 31:21-50. https://doi. org/10.1111/j.1439-0485.2010.00359.x

Burdett HL, Carruthers M, Donohue P, et al (2014) Effects of high temperature and $\mathrm{CO}_{2}$ on intracellular DMSP in the cold-water coral Lophelia pertusa. Mar Biol 161:1499-1506

Büscher JV, Form AU, Riebesell U (2017) Interactive effects of ocean acidification and warming on growth, fitness and survival of the cold-water coral Lophelia pertusa under different food availabilities. Front Mar Sci 4. https://doi.org/10.3389/fmars.2017.00101

Caldeira K, Wickett ME (2003) Anthropogenic carbon and ocean pH. Nature 425:365-365. https://doi.org/10.1038/425365a

Carreiro-Silva M, Cerqueira T, Godinho A, et al (2014) Molecular mechanisms underlying the physiological responses of the cold-water coral Desmophyllum dianthus to ocean acidification. Coral Reefs 33:465-476. https://doi.org/10.1007/ s00338-00014-01129-00332

Chen X, Tung K-K (2014) Varying planetary heat sink led to globalwarming slowdown and acceleration. Science 345:897-903. https:// doi.org/10.1126/science. 1254937

Cheng L, Zheng F, Zhu K (2015) Distinctive Ocean interior changes during the recent warming slowdown. Sci Rep 5:14346. https://doi. org/10.11038/srep14346

Church JA, White NJ, Konikow LF, et al (2011) Revisiting the Earth's sea-level and energy budgets from 1961 to 2008n.d.. Geophys Res Lett 38:L18601. https://doi.org/10.11029/12011GL048794

Cicerone R, Orr J, Brewer P, et al (2004) The ocean in a high-CO2 world. Oceanography 17:72-78

CIESM (2008) Impacts of ocean acidification on biological, chemical and physical systems in the Mediterranean and black seas. In: Briand F (ed) CIESM workshop monographs, Monaco, p 124

Clark MR, Althaus F, Schlacher TA, et al (2015) The impacts of deepsea fisheries on benthic communities: a review. ICES J Mar Sci 73:i59-i69. https://doi.org/10.1093/icesjms/fsv1123

Clippele LHD, Gafeira J, Robert K, et al (2016) Using novel acoustic and visual mapping tools to predict the small-scale spatial distribution of live biogenic reef framework in cold-water coral habitats. Coral Reefs 36:255-268

D'Ortenzio F, Antoine D, Marullo S (2008) Satellite-driven modeling of the upper ocean mixed layer and air-sea $\mathrm{CO} 2$ flux in the Mediterranean Sea. Deep-Sea Res Part 1 Oceanogr Res Pap 55:405-434

Davies AJ, Guinotte JM (2011) Global habitat suitability for framework-forming cold-water corals. PLoS One 6:e18483. https:// doi.org/10.11371/journal.pone.0018483

Davies AJ, Wisshak M, Orr JC, et al (2008) Predicting suitable habitat for the cold-water coral Lophelia pertusa (Scleractinia). Deep-Sea Res Part 1 Oceanogr Res Pap 55:1048-1062

De Mol L, van Rooij D, Pirlet H, et al (2011) Cold-water coral habitats in the Penmarch and Guilvinec Canyons (Bay of Biscay): Deepwater versus shallow-water settings. Mar Geol 282:40-52

Desbruyères DG, Purkey SG, McDonagh EL, et al (2016) Deep and abyssal ocean warming from 35 years of repeat hydrography. Geophys Res Lett 43. https://doi.org/10.1002/2016GL070413

Dodds LA, Roberts JM, Taylor AC, et al (2007) Metabolic tolerance of the cold-water coral Lophelia pertusa (Scleractinia) to temperature and dissolved oxygen change. J Exp Mar Biol Ecol 349:205-214

Duineveld GCA, Lavaleye MSS, Bergman MJN, et al (2007) Trophic structure of a cold-water coral mound community (Rockall Bank, NE Atlantic) in relation to the near-bottom particle supply and current regime. Bull Mar Sci 81:449-457

England MH, McGregor S, Spence P, et al (2014) Recent intensification of wind-driven circulation in the Pacific and the ongoing warming hiatus. Nat Clim Chang 4:222-227

Feely RA, Sabine CL, Lee K, et al (2004) Impact of anthropogenic CO2 on the $\mathrm{CaCO} 3$ system in the oceans. Science 305:362-366

Feely RA, Sabine CL, Byrne RH, et al (2012) Decadal changes in the aragonite and calcite saturation state of the Pacific Ocean. Glob Biogeochem Cycles 26:GB3001

Ferrier-Pagès C, Gattuso J-P, Jaubert J (1999) Effect of small variations in salinity on the rates of photosynthesis and respiration of the zooxanthellate coral Stylophora pistillata. Mar Ecol Progr Ser 181:309-314 
Fillinger L, Richter C (2013) Vertical and horizontal distribution of Desmophyllum dianthus in Comau Fjord, Chile: a cold-water coral thriving at low $\mathrm{pH}$. PeerJ 1:e194. https://doi.org/10.7717/peerj.7194

Form AU, Riebesell U (2012) Acclimation to ocean acidification during long-term $\mathrm{CO} 2$ exposure in the cold-water coral Lophelia pertusa. Glob Change Biol 18:843-853. https://doi. org/10.1111/j.1365-2486.2011.02583.x

Fosså JH, Mortensen PB, Furevik DM (2002) The deep-water coral Lophelia pertusa in Norwegian waters: distribution and fishery impacts. Hydrobiologia 471:1-12

Freiwald A, Beuck L, Rüggeberg A, et al (2009) The white coral community in the Central Mediterranean Sea revealed by ROV surveys. Oceanography 22:36-52

Fyfe JC, Meehl GA, England MH, et al (2016) Making sense of the early-2000s warming slowdown. Nat Clim Chang 6:224-228. https://doi.org/10.1038/nclimate2938

Gammon MJ, Tracey DM, Marriott PM, et al (2018) The physiological response of the deep-sea coral Solenosmilia variabilis to ocean acidification, e5236. PeerJ 6. https://doi.org/10.7717/peerj.5236

Gass SE, Willison JHM (2005) An asessment of the distribution of deep-sea corals in Atlantic Canada by using both scientific and local forms of knowledge. In: Freiwald A, Roberts JM (eds). Cold-water corals and ecosystems. Springer, Berlin, Heidelberg, pp 223-245

Gattuso J-P, Magnan A, Billé R, et al (2015) Contrasting futures for ocean and society from different anthropogenic $\mathrm{CO} 2$ emmissions scenarios. Science 349:aac4722. https://doi.org/10.1126/science. aac4722

Georgian SE, DeLeo D, Durkin A, et al (2016a) Oceanographic patterns and carbonate chemistry in the vicinity of cold-water coral reefs in the Gulf of Mexico: implications for resilience in a changing ocean. Limnol Oceanogr 61:648-665

Georgian SE, Dupont S, Kurman M, et al (2016b) Biogeographic variability in the physiological response of the cold-water coral Lophelia pertusato ocean acidification. Mar Ecol 37:1345-1359

Giorgi F (2006) Climate change hot-spots. Geophys Res Lett 33:L08707. https://doi.org/10.01029/02006GL025734

Giorgi F, Lionello P (2008) Climate change projections for the Mediterranean region. Glob Planet Chang 63:90-104

Giorgi F, Whetton PH, Jones RG, et al (2001) Emerging patterns of simulated regional climatic changes for the 21 st century due to anthropogenic forcings. Geophys Res Lett 28:3317-3320

Gori A, Orejas C, Madurell T, Bramanti L, et al (2013) Bathymetrical distribution and size structure of cold-water coral populations in the Cap de Creus and Lacaze-Duthiers canyons (northwestern Mediterranean). Bigeosciences 10:2049-2060

Gori A, Ferrier-Pagès C, Hennige SJ, et al (2016) Physiological response of the cold-water coral Desmophyllum dianthus to thermal stress and ocean acidification. PeerJ 4:e1606. https://doi. org/10.7717/perj.1606

Goyet C, Hassoun AER, Gemayel E, et al (2016) Thermodynamic forecasts of the Mediterranean Sea acidification. Mediterr Mar Sci 17:508-518

Guinotte JM, Orr J, Cairns S, et al (2006) Will human-induced changes in seawater chemistry alter the distribution of deep-sea scleractinian corals? Front Ecol Environ 4:141-146

Hansen J, Sato M (2016) Regional climate change and national responsibilities. Environ Res Lett 11:034009

Hansen J, Sato M, Kharecha P, et al (2011) Earth's energy imbalance and implications. Atmos Chem Phys 11:13421-13449

Hassoun AER, Gemayel E, Krasakopoulou E, et al (2015) Acidification of the Mediterranean Sea from anthropogenic carbon penetration. Deep-Sea Res Part 2 Top Stud Oceanogr 102:1-15

Hausfather Z, Cowtan K, Clarke DC, et al (2017) Assessing recent warming using instrumentally homogeneous sea surface temperature records. Sci Adv 3:e1601201
Hennige SJ, Wicks LC, Kamenos NA, et al (2014) Short-term metabolic and growth responses of the cold-water coral Lophelia pertusa to ocean acidification. Deep-Sea Res Part 2 Top Stud Oceanogr 99:27-35. https://doi.org/10.1016/j.dsr1012.2013.1007.1005

Hennige SJ, Wicks LC, Kamenos NA, et al (2015) Hidden impacts of ocean acidification to live and dead coral framework. Proc R Soc B 282:20150990

Hourigan TF (2009) Managing fishery impacts on deep-water coral ecosystems of the USA: emerging best practices. Mar Ecol Progr Ser 397:333-340

Hovland M, Vasshus S, Indreeide A, et al (2002) Mapping and imaging deep-sea coral reefs off Norway, 1982-2000. Hydrobiologia 471:13-17

IPCC (2013) Climate change 2013: the physical science basis. Contribution of Working Group I to the Fifth Assessment Report of the Intergovernmental Panel on Climate Change. In: Stocker TF, Qin D, Plattner G-K, et al (eds) Cambridge University Press, Cambridge

Jantzen C, Häussermann V, Försterra G, et al (2013) Occurrence of a cold-water coral along natural $\mathrm{pH}$ gradients (Patagonia, Chile). Mar Biol 160:2597-2607. https://doi.org/10.1007/ s00227-00013-02254-00220

Karl TR, Arguez A, Huang B, et al (2015) Possible artifacts of data biases in the recent global surface warming hiatus. Science 348:1469-1472

Kiriakoulakis K, Fisher E, Wolff GA, et al (2005) Lipids and nitrogen isotopes of two deep-water corals from the North-East Atlantic: initial results and implications for their nutrition. In: Freiwald A, Roberts JM (eds) Cold-water corals and ecosystems. Springer, Berlin, Heidelberg, pp 715-729

Kleypas JA, Feely RA, Fabry VJ, et al (2006) Impacts of ocean acidification on coral reefs and other marine calcifiers: a guide to future research. Report of a workshop sponsored by the National Science Foundation, the National Oceanographic and atmospheric administration, And the US geological survey 96 p. Available at: www. isseucaredu/Florida/

Kosaka Y, Xie S-P (2013) Recent global-warming hiatus tied to equatorial Pacific surface cooling. Nature 501:403-407. https://doi. org/10.1038/nature12534

Kurman MD, Gómez CE, Georgian SE, et al (2017) Intra-specific variation reveals potential for qdaptation to ocean acidification in a cold-water coral from the Gulf of Mexico. Front Mar Sci 4:111. https://doi.org/10.3389/fmars.2017.00111

Landschützer P, Gruber N, Bakker DCE (2016) Decadal variations and trends of the global ocean carbon sink. Global Biogeochem Cycles 30:1396. https://doi.org/10.1002/2015GB005359

Law CS, Rickard GJ, Mikaloff-Fletcher SE, et al (2016) The New Zealand EEZ and south West Pacific. Synthesis report RA2, marine case study. Climate Changes, Impacts and Implications (CCII) for New Zealand to 2100. MBIE contract C01X1225, 41pp

Levermann A, Clark PU, Marzeion B, et al (2013) The multimillennial sea-level commitment of global warming. Proc Natl Acad Sci 110:13745-13750

Levitus S, Antonov JI, Boyer RP, et al (2012) World ocean heat content and thermosteric sea level change $(0-2000 \mathrm{~m}), 1955-2010,1955$ 2010. Geophys Res Lett 39:L10603 https://doi.org/10.11029/1201 2GL051106

Lewandowsky S, Cook J, Lloyd E (2016) The 'Alice in Wonderland' mechanics of the rejection of (climate) science: simulating coherence by consiracism. Synthese 195:175-196. https://doi. org/10.1007/s11229-11016-11198-11226

Llovel W, Willis K, Landerer FW, et al (2014) Deep-ocean contribution to sea level and energy budget not detectable over the past decade. Nat Clim Chang 4:1031-1035. https://doi.org/10.1038/ nclimate 2387 
Lunden JJ, Nicholl CGM, Sears CR, et al (2014) Acute survivorship of the deep-sea coral Lophelia pertusa from the Gulf of Mexico under acidification, warming, and deoxygenation. Fron Mar Sci 1:78. https://doi.org/10.3389/fmars.2014.00078

Maier C, Hegeman J, Weinbauer MG, et al (2009) Calcification of the cold-water coral Lophelia pertusa under ambient and reduced pH. Biogeosciences 6:1671-1680

Maier C, Watremez P, Taviani M, et al (2012) Calcification rates and the effect of ocean acidification on Mediterranean cold-water corals. Proc R Soc Lond 279:1713-1723. https://doi.org/10.1098/ rspb.2011.1763

Maier C, Bils F, Weinbauer M, Watremez P, et al (2013a) Respiration of Mediterranean cold-water corals is not affected by ocean acidification as projected for the end of the century. Biogeosciences 10:5671-5680. https://doi.org/10.5194/bg-5610-5671-2013

Maier C, Schubert A, Berzunza Sànchez MM, et al (2013b) End of the century pCO2 levels do not impact calcification in Mediterranean cold-water corals. PLoS One 8:e2655. https://doi.org/10.1371/journal.pone. 0062655

Maier C, Popp P, Sollfrank N, et al (2016) Effects of elevated pCO2 and feeding on net calcification and energy budget of the Mediterranean cold-water coral Madrepora oculata. J Exp Biol 219:3208

Malanotte-Rizzoli P, Font J, García-Ladona E, et al (2014) Physical forcing and physical/biochemical variability of the Mediterranean Sea: a review of unresolved issues and directions for future research. Ocean Sci 10:281-322

Mariotti A, Zeng N, Yoon J-H, et al (2008) Mediterranean water cycle changes: transition to drier 21st century conditions in observations and CMIP3 simulations. Environ Res Lett 3:044001 10.041088/041748-049326/044003/044004/044001

Mastrototaro F, D'Onghia G, Corriero G, et al (2010) Biodiversity of the white coral bank off Cape Santa Maria di Leuca (Mediterranean Sea): an update. Deep-Sea Res Part 2 Top Stud Oceanogr 57:412-430

McCulloch M, Trotter J, Montagna P, et al (2012) Resilience of cold-water scleractinian corals to ocean acidification: boron isotopic systematics of $\mathrm{pH}$ and saturation state up-regulation. Geochim Cosmochim Acta 87:21-34. https://doi.org/10.1016/j. gca.2012.1003.1027

McGregor S, Timmermann A, Stuecker MF, et al (2014) Recent Walker circulation strengthening and Pacific cooling amplified by Atlantic warming. Nat Clim Chang 4:888-892. https://doi.org/10.1038/ nclimate 2330

Meehl GA, Arblaster JM, Fasullo JT, et al (2011) Model-based evidence of deep-ocean heat uptake during surface-temperature hiatus periods. Nat Clim Chang 1:360-364. https://doi.org/10.1038/ nclimate 1229

Mikaloff-Fletcher SE, Gruber N, Jacobson AR, et al (2006) Inverse estimates of anthropogenic $\mathrm{CO}_{2}$ uptake, transport, and storage by the ocean. Global Biogeochem Cycles 20. https://doi. org/10.1029/2005GB002530

Millero FJ, Morse J, Chen CT (1979) The carbonate system in the western Mediterranean Sea. Deep-Sea Res Part 1 Oceanogr Res Pap 26A: $1395-1404$

Mortensen PB (2001) Aquarium observations on the deep-water coral Lophelia pertusa (L., 1758) (Scleractinia) and selected associated invertebrates. Ophelia 54:83-104

Movilla J, Gori A, Calvo E, et al (2014a) Resistance of two Mediterranean cold-water coral species to low-pH conditions. Water 5:59-67

Movilla J, Orejas C, Calvo E, et al (2014b) Differential response of two Mediterranean cold-water coral species to ocean acidification. Coral Reefs 33:675-686

Naumann MS, Orejas C, Ferrier-Pagès C (2013a) High thermal tolerance of two Mediterranean cold-water coral species maintained in aquaria. Coral Reefs 32:749. https://doi.org/10.1007/ s00338-00013-01011-00337
Naumann MS, Orejas C, Ferrier-Pagès C (2013b) Species-specific physiological response by the cold-water corals Lophelia pertusa and Madrepora oculata to variations within their natural temperature range. Deep-Sea Res Part 2 Top Stud Oceanogr 99:36-41

Nykjaer L (2009) Mediterranean Sea surface warming 1985-2006. Clim Res 39:11-17

Orejas C, Gori A, Lo Iacono C, et al (2009) Cold-water corals in the Cap de Creus canyon, northwestern Mediterranean: spatial distribution, density and anthropogenic impact. Mar Ecol Progr Ser 397:37-51

Orr JC, Maier-Reimer E, Mikolajewicz U, et al (2001) Estimates of anthropogenic carbon uptake from four three-dimensional global ocean models. Global Biogeochem Cycles 15:43-60

Orr JC, Fabry VJ, Aumont O, et al (2005a) Anthropogenic Ocean acidification over the twenty-first century and its impact on calcifying organisms. Nature 437:681-686

Orr JC, Pantoja S, Pörtner HO (2005b) Introduction to special section: the ocean in a high-CO2 world. J Geophys Res 110:C09S01. https:// doi.org/10.1029/2005JC003086

Pierce DS, Gleckler PJ, Barnett TP, et al (2012) The fingerprint of human-induced changes in the ocean's salinity and temperature fields. Geophys Res Lett 39:L21704. https://doi.org/10.21029/220 12GL053389

Purkey SG, Johnson GC (2010) Warming of global abyssal and deep Southern Ocean waters between the 1990s and 2000s: contributions to global heat and sea level rise budgets. J Clim 23:6336-6351. https://doi.org/10.1175/2010JCLI3682.6331

Revelle R, Suess HE (1957) Carbon dioxide exchange between atmosphere and ocean and the question of an increase of atmospheric $\mathrm{CO} 2$ during the past decades. Tellus 9:18-27. https://doi. org/10.3402/tellusa.v9i1.9075

Rhein M, Rintoul SR, Aoki S, et al (2013) Observations: ocean. In: Stocker TF, Qin D, Plattner G-K, et al (eds) Climate change 2013: the physical science basis contribution of working group I to the fifth assessment report of the Intergovernmental Panel on Climate Change. Cambridge University Press, Cambridge, New York

Riebesell U, Gattuso JP (2015) Lessons learned from ocean acidification research. Nat Clim Chang 5:12-14

Rixen M, Beckers JM, Levitus S, et al (2005) The western Mediterranean deep water: a proxy for climate change. Geophys Res Lett 32:L12608

Roberts JM, Davies AJ, Henry LA, et al (2009) Mingulay reef complex: an interdisciplinary study of cold-water coral habitat, hydrograqphy and biodiversity. Mar Ecol Progr Ser 397:139-151

Roberts JM, Murray F, Anagnostou E, et al (2016) Cold-water corals in an era of rapid global change: are these the deep ocean's most vulnerable ecosystems? In: Goffredo S, Dubinsky Z (eds) The Cnidaria, past, present and future. Springer, Cham, pp 593-606

Rodolfo-Metalpa R, Montagna P, Aliani S, et al (2015) Calcification is not the Achilles' heel of cold-water corals in an acidifying ocean. Glob Chang Biol 21:2238-2248

Rogers AD (1999) The biology of Lophelia pertusa (Linnaeus 1758) and other deep-water reef-forming corals and impacts from human activities. Int Rev Hydrobiol 84:315-406

Rowden AA, Guinotte JM, Baird SJ, et al (2013) Developing predictive models for the distribution of vulnerable marine ecosystems in the South Pacific region. New Zealand aquatic environment and biodiversity report $120: 70 p$

Sabine CL, Feely RA, Gruber N, et al (2004) The oceanic sink for anthropogenic CO2. Science 305:367-371

Savini A, Vertino A, Marchese F, et al (2014) Mapping cold-water coral habitats at different scales within the Northern Ionian Sea (Central Mediterranean): an assessment of coral coverage and associated vulnerability. PLoS One 9:e87108

Smith AM, Williams MJM (2015) The carbonate mineralogy and distribution of habitat-forming deep-sea corals in the southwest pacific region. Deep-Sea Res Part 1 Oceanogr Res Pap 100:88-104 
Song J, Wang Y, Tang J (2016) A hiatus of the greenhouse effect. Sci Rep 6:33315

Sumida PYG, Yoshinaga MY, Madureira LASP, et al (2004) Seabed pockmarks associated with Deepwater corals off SE Brazilian continental slope, Santos Basin. Mar Geol 207:159-167

Taviani M, Freiwald A, Zibrowius H (2005) Deep coral growth in the Mediterranean Sea: an overview. In: Freiwald A, Roberts JM (eds) Cold-water corals and ecosystems. Springer, Berlin, Heidelberg, pp 137-156

Thresher RE, Tilbrook B, Fallon S, et al (2011) Effects of chronic low carbonate saturation levels on the distribution, growth and skeletal chemistry of deep-sea corals and other seamount megabenthos. Mar Ecol Progr Ser 442:87-99

Tittensor DP, Baco AR, Hall-Spencer JM, et al (2010) Seamounts as refugia from ocean acidification for cold-water stony corals. Mar Ecol 31:212-225

Touratier F, Goyet C (2009) Decadal evolution of anthropogenic $\mathrm{CO} 2$ in the northwestern Mediterranean Sea from the mid1990s to the mid-2000s. Deep-Sea Res Part 1 Oceanogr Res Pap 56:1708-1716

Touratier F, Goyet C (2011) Impact of the Eastern Mediterranean Transient on the distribution of anthropogenic $\mathrm{CO} 2$ and first estimate of acidification for the Mediterranean Sea. Deep-Sea Res Part 1 Oceanogr Res Pap 58:1-15

Tracey DM, Rowden AA, Mackay KA, et al (2011) Habitat-forming cold-water corals show affinity for seamounts in the New Zealand region. Mar Ecol Progr Ser 430:1-22

Turley CM (1999) The changing Mediterranean Sea - a sensitive ecosystem? Progr Oceanogr 44:387-400

Turley CM, Roberts JM, Guinotte JM (2007) Corals in deep-water: will the unseen hand of ocean acidification destroy cold-water ecosystems? Coral Reefs 26:445-448

Vargas-Yáñez M, Moya F, Tel E, et al (2009) Warming and salting in the western Mediterranean during the second half of the 20th century: inconsistencies, unknown and the effect of data processing. Sci Mar 73:7-28

Wall M, Ragozzola F, Foster LC, et al (2015) pH up-regulation as a potential mechanism for the cold-water coral Lophelia pertusa to sustain growth in aragonite undersaturated conditions. Biogeosciences 12:6869-6880
Waller RG, Tyler PA (2005) The reproductive biology of two deepwater, reef-building scleractinians from the NE Atlantic Ocean. Coral Reefs 24:514-522

Waller RG, Tyler PA, Gage JD (2005) Sexual reproduction in three hermaphroditic deep-sea Caryophyllia species (Anthozoa: Scleractinia) from the NE Atlantic Ocean. Coral Reefs 24:594-602

Wheeler AJ, Beyer A, Freiwald A, et al (2007) Morphology and environment of cold-water coral carbonate mounds on the NW European margin. Int J Earth Sci 96:37-56

Yan X-H, Boyer T, Trenberth K, et al (2016) The global warming hiatus: slowdown or redistribution. Earth's Future 4:472-482. https:// doi.org/10.1002/2016EF000417

Zeebe RE, Ridgwell A, Zachos JC (2016) Anthropogenic carbon release rate unprecedented during the past 66 million years. Nat Geosci 9:325-329

Zibrowius H, Gili J-M (1990) Deep-water Scleractinia (Cnidaria: Anthozoa) from Namibia, South Africa, and Walvis ridge, southeastern Atlantic. Sci Mar 54:19-46

\section{Cross References}

Angeletti L, Bargain A, Campiani E, et al (this volume) Cold-water coral habitat mapping in the Mediterranean Sea: methodologies and perspectives

Hayes D, Schroeder K, Poulain, PM, et al (this volume) Review of the circulation and characteristics of intermediate water masses of the Mediterranean--implications for cold-water coral habitats

Lartaud F, Mouchi V, Chapron L, et al (this volume) Growth patterns of Mediterranean calcifying cold-water corals

Lo Iacono C, Savini A, Huvenne VAI, et al (this volume) Habitat mapping of cold-water corals in the Mediterranean Sea

Orejas C, Taviani M, Ambroso S, et al (this volume) Cold-water coral in aquaria: advances and challenges. A focus on the Mediterranean

Reynaud S, Ferrier-Pagès C (this volume) Biology and ecophysiology of Mediterranean cold-water corals

Skliris N (this volume) The Mediterranean is getting saltier: from the past to the future 